\title{
Efficiency forecasting for municipal solid waste recycling in the context on sustainable development of economy
}

\author{
Alla Tkachenko ${ }^{1}$, Nataliia Levchenko ${ }^{1}$, Ganna Shyshkanova ${ }^{2, *}$, Dmytro Plynokos ${ }^{3}$, and Marharyta Kovalenko ${ }^{3}$ \\ ${ }^{1}$ National University “Zaporizhzhia Polytechnic”, Department of Entrepreneurship, Trade and Exchange activities, 64 Zhukovskogo Str., \\ Zaporizhzhia, 69063, Ukraine \\ ${ }^{2}$ National University "Zaporizhzhia Polytechnic", Applied Mathematics Department, 64 Zhukovskogo Str., Zaporizhzhia, 69063, Ukraine \\ ${ }^{3}$ National University “Zaporizhzhia Polytechnic”, Economics and Customs Department, 64 Zhukovskogo Str., Zaporizhzhia, 69063, \\ Ukraine
}

\begin{abstract}
Ukraine's further economic growth should be directed by Government Sustainable Development Strategy for harmonization of economy, environmental and social protection. One of the important modern problems is pollution by waste. The feasibility of introducing an eco-project for the municipal solid waste recycling is substantiated at the present research. The complex mathematical model of profit forecast is developed, which shows the tariffs influence on profitability of eco-project on construction of the plant for municipal solid waste recycling in Poltava region of Ukraine. The authors determine and analyse the dependences of the expected eco-project revenue from the change in tariffs for waste management services for each of the consumer categories. Two scenarios of economic development (inertial and innovative) are compared and resulted that the both scenarios have environmental and economic effect, so they are investment attractive. Emphasis is placed on the shortcomings and gaps of the existing tariff policy. The paper demonstrates lack of incentives for the development of business recycling under the existing tariff policy, so to establish a single tariff is proposed uniting the services cost for the removal, sorting, processing and disposal of the waste and also without dividing by consumer categories.
\end{abstract}

\section{Introduction}

The choice of Ukraine as a point for further economic growth of the Sustainable Development Strategy pushes business, politicians, the scientific community, ordinary citizens to rethink the traditional model of economy and the need to transform it from linear to circular, based on the principle of sustainable development - "take, make, reuse". The linear model of economy is based on the principle of "take, make, waste". Whereas this linear model is the dominant in Ukraine since the Industrial Revolution. It has led to a number of serious problems, among which is the most magnitude and significance problem is Municipal Solid Waste (hereinafter - MSW) generation, which does not only hinder the socioeconomic development of the country, but also leads to environmental destruction [1, p. 505].

According to the Law of Ukraine "On Waste" dated 05.03.1998, No. 187/98 [2] (as amended on 01.05.2019) (hereinafter - the Law of Ukraine, No. 2189-VII) formed in the course of human life and activity in residential and non-residential buildings and are not used at their place of accumulation [2]. The Law, No 2189-VII is fundamental, based on its approach the approach foreseen in Directive 2008/98/EC of the European Parliament and of the Council on waste [3].
As of the end of 2018, more than 12.5 billion tonnes of MSW hazard classes I, IV, or 21.5 thousand tonnes per $\mathrm{km}^{2}$ of state territory have been accumulated in designated areas in Ukraine [4], making the country one of the world's leaders in terms of waste. Landfill and disposal services at the polygons and landfills, which at the end of 2018 in Ukraine calculated more than 5.5 thousand units with a total area of over 9 thousand hectares, of which 305 $(5.6 \%)$ are dominant overloaded, and 1.6 thousand units (30\%) do not meet environmental safety standards [5]. The most successful way to solve this problem, from the experience of European countries, is to move from the traditional to the circular model of the economy, in which waste is perceived not as garbage, but as secondary resources [6].

"Sub-regional Waste Management Strategy" (hereinafter referred to as the Strategy) [7], developed for the Poltava Oblast for this purpose by European experts with the support of Deutsche Gesellschaft für Internationale Zusammenarbeit (GIZ) $\mathrm{GmbH}$ in the framework of the international project "Governance Reform in Eastern Ukraine" (PN 11-2129.2-001.00). The strategy envisages the implementation of an eco-project for the construction of a modern landfill and five sorting stations, as well as a waste recycling plant.

The feasibility of implementing the eco-project is substantiated by:

* Corresponding author: shyann@i.ua 
- amendments to the Law of Ukraine No. 2189-VII [2] on the prohibition of the disposal of unprocessed waste; - the need to protect fertile soils from contamination and to prevent the further expansion of the areas of the bacteria dumpsites of landfills;

- the absence of any solid waste processing enterprises in the region.

The success of its implementation is hampered by low tariffs on waste management services that do not create incentives for business recycling.

It is convinced that the waste recycling business is economically and environmentally effective. We conducted a comprehensive study of eco-project management effectiveness for the construction of solid waste processing plant to prove this statement.

\section{Literature review}

Nowadays, Ukraine is undergoing a complex process of socio-economic transformation, in which it is of utmost importance for society to realize the significance of the Sustainable Development Strategy chosen by the EU countries and Ukraine, which should unite the society in deciding three basic interconnected challenges economic growth, environmental protection and social protection for all members of the society [8].

The focus is on sustainable development goals and the strategic framework for its providing in Ukraine, which will ensure macroeconomic stability, environmental balance and social cohesion in practice, and will serve as a common basis for further transformations [9]. Ukraine's place in the world ranking according to the criteria of the Index of Sustainable Development (ISD) is analysed in [10]. The main strategic stages of ensuring sustainable development in Ukraine are proposed in [10].

Waste has become an environmental problem in Ukraine. As plastic consists of harmful pollutants, it causes a significant threat to atmosphere. The most serious long-term effects of plastic pollution are groundwater, land and air pollutions, threat to animals, disturb of the food chain [11]. The issue of waste disposal is being discussed and it is obvious that at every stage of the process, it is possible to make money from waste [12]. Waste disposal includes reducing the local pollution and saving landfill space.

During the last two decades, EU legislation has put increasing pressure on member countries to achieve specified recycling targets for MSW [13]. Moreover, paper [13] compares MSW management practices in various EU countries to identify the characteristics and key issues from a waste management. Therefore, it was concluded that the waste recycling is a multi-disciplinary problem that needs to be considered at different decision levels simultaneously [13].

Management of MSW is a major challenge for most of the urban local authorities in developing countries primarily due to the rising of urban population and per capita waste generation rate [11]. Improper handling of MSW will create the city unsuitable for living.

The paper [14] illustrates an overview of the past and present MSW management strategies in China. A comparison is made with other developed and developing countries to identify and analyze the existing problems and evaluate some effective suggestion to overcome the limitations. Increase waste recycling and proper taxation system for MSW disposal are essential to improve MSW management in China [14].

The economic and environmental aspects of sustainability are considered on the waste recycling process in Malaysia [12], Iran [15], India [11], Canada [16]. The equilibrium strategies are obtained and various managerial insights are revealed, moreover, more the recyclability degree of the waste leads to higher profits for the members [15]. Economic outputs, expenditure and profits, and business sizes for both public and private waste services were studied [16].

Economy of the society makes great influence on the waste situation. Some of the socioeconomic variables are significantly correlated with solid waste generation [12].

The results of [17] show that the specific charge policy can improve the performance of residents' separation behavior, which is a more effective way to reduce the MSW and increase the collection rate of domestic recyclable resources. To resolve the issue of the urban waste management, it is necessary to balance the profit of charge point of agents in the system [17]. This shows the relevance of development the model, which indicates the influences of waste management tariffs on the profit from waste recycling in Ukraine.

Ackermann [18] acknowledged the importance of recycling in the face of economic growth and proved its effectiveness if it created a favourable environment for eco-projects. Rifkin [19] emphasized the importance of recycling in the industrial revolution and argued for the need to take into account both environmental and economic efficiency during deciding on the implementation of eco-projects. Tkachenko, Levchenko, Pozhuieva, and Shupryna [20] underlined the need to make the link between green growth of agribusiness volumes and its impact on the environment, while emphasizing the importance of making significant decisions during implementing eco-projects through ecomathematical modelling analysis.

Focusing on the issues of assessing the profitability of eco-projects, Dovha [21] substantiated her own approach to the classification of indicators for the assessment of the ecological and economic efficiency of household waste recycling in Ukraine. Bobylev, Goryacheva and Nemova [22] concentrated on a project-based approach to developing household waste recycling and evaluating its effectiveness. Scientists emphasize the need to reconcile the interdependence of economic and environmental interests to address ways of adapting businesses to new business conditions. The necessity of application of economic and mathematical modelling by the method of correlation and regression analysis in estimating the expected effect of eco-projects is substantiated in $[12,17$, 22]. 


\section{Calculation methodology}

Correlation and regression analysis are the main one in the study of the relationship of phenomena and therefore it is a necessary modern tool in engineering and economic research. This is a quantitative method for determining the density and the type of the mathematical function in a causal dependence between variables. Naturally, it is constantly developing and improving for different applied models [23].

The method of least squares is often used to generate estimators and other statistics in regression analysis. It was shown how difficult questions could be answered by developing simple models with simple interpretation of parameters for diversity of applications [23, 24].

The first attempts to set up a waste recycling business in Ukraine were unsuccessful for reasons such as a lack of recyclables and the lack of economic incentives for MSW recycling. Therefore, when deciding on the implementation of eco-projects for waste recycling, first, the question arises of the generation of waste at mediumterm and long-term horizons.

The calculation of the expected volumes of MSW was performed according to the methodology stipulated by the Order of the Ministry of Housing and Communal Services of Ukraine "On Approval of the Rules for Determining the Standards of Provision of Services for the Removal of Household Waste" No. 309, July 30, 2010 (with changes and additions) [25]. It is based on:

- population change projections, determined by foresight methodology;

- prospects for economic development of territories and rates of growth of incomes of the population;

- waste generation standards, calculated taking into account the area of residence and improvement of house.

Projections of population change for the period up to 2040 are determined according to the data of the Demographic forecast of population development in Poltava for the period up to 2050 , carried out within the framework of the project "Integrated Urban Development of Ukraine" No. 2015.2071.7.001 [26] by the method of transportation of age group.

The demographic forecast [26] is based on a scenario approach, which envisages two scenarios of economic development in the Poltava sub-region:

- inertial, which is expected to gradually reduce the population due to: falling fertility rates and reducing life expectancy, negative external migration, etc.;

- an innovative one that is expected to slow down the population and, starting from 2030, gradually grow, thanks to the development of industry and internal "village-city" migration [26].

The calculation of the expected volumes of MSW is performed according to the standards of formation of MSW, provided by IBN B.2.2-12:2018 “Territory planning and development" [27] and [28] in Table 1.

In addition, the data is presented according to the results of the study of the morphological composition of MSW, carried out within the framework of the GIZ project under the Comprehensive Program for Solid Waste Management in Poltava region for 2017-2021 [28] in Table 2.
The calculation of the expected income from the provision of solid waste management services was made taking into account the tariff forecasts determined by the Law of Ukraine "On Housing and Communal Services" of 09.11.2017 No. 2189-VIII [29] by three categories of consumers as:

I - the population;

II - budgetary institutions;

III - other consumers.

Table 1. Norms for municipal solid waste generation.

\begin{tabular}{|c|c|c|c|}
\hline Indicators & $\begin{array}{c}\text { Objects for } \\
\text { the } \\
\text { formation of } \\
\text { MSW }\end{array}$ & $\begin{array}{c}\text { Quantity, } \\
\mathbf{~ k g}\end{array}$ & $\begin{array}{c}\text { Annual rate of } \\
\text { formation of } \\
\text { MSW on the } \\
\text { settlement unit, } \\
\mathbf{m}^{3}\end{array}$ \\
\hline $\begin{array}{c}\text { Average in the } \\
\text { settlement with } \\
\text { the account of } \\
\text { pendulum } \\
\text { migration }\end{array}$ & 1 person & $250-350$ & $1.8-2.5$ \\
\hline
\end{tabular}

Tariff estimates, in contrast to the existing tariffs (which include only the cost of removal and disposal of waste), are determined taking into account the costs of each of the waste management services: removal, sorting, processing and disposal.

The separate collection costs by collected (sorting of useful components of household waste) are not taken into account when setting prices/tariffs for a household waste service in accordance with the amendments made to the Order of formation of tariffs for services for the removal of household waste, approved by the Cabinet of Ministers of Ukraine on 26.07.2006, No. 1010 [30] by the Cabinet of Ministers of Ukraine "On Amendments to certain CMU Resolutions" of March 27, 2018, No. 318 [31]. Estimated revenue from MSW recycling has been calculated taking into account the morphological composition of the rubbish (see Table 2) and the expected volume of household waste for the period up to 2040.

Particular attention is paid to plastic waste, since according to the Draft Law of Ukraine "On Waste Management" dated 22.10.2019, No. 2207-1 [32], submitted by the Ministry of Ecology and Natural Resources of Ukraine for consideration by the Parliament, plastic waste is secondary resources.

The expected volume of plastic waste is calculated based on the estimated volume of waste and the percentage of plastic determined from the GIZ morphological studies.

The expected level of suitability of plastic waste for recycling has been established, taking into account the identification of plastic waste by ISO 1043 code "Plastics - Symbols and abbreviated terms" [33].

The prices of clean PET flakes and secondary crystalline granules, as well as the volume of plastic waste (recoverable), determined by the expected future price of the sale of secondary resources.

Let's consider the time series of the average tariff for MSW management services for population $\left(y_{1}, \mathrm{UAH} / \mathrm{m}^{3}\right)$ based on the statistics on Poltava sub-region [4]. 
The statistics is presented in Table 3 for each of the categories of service consumers, and above all for consumers of Group I - population. Thanks to smoothing the levels of the time series for further forecasting, we find an analytical dependence of the nonlinear change in the indicator by years $(x)$.

It was proposed to consider the equation that describes this model as a quadratic regression, whose coefficients are found by the least squares method with the prior linearization

$$
\hat{y}_{1}=-3861.39+0.00096 \cdot x^{2} .
$$

The next formula is used in order to calculate the expected revenue from the provision of MSW providing services for the population of Poltava sub-region $D_{t n}$, UAH million

$$
D_{t n}=y_{1} \cdot 10^{-6} \cdot x_{1} \cdot x_{2} .
$$

where $x_{1}$ is the MSW rate per person per year, $\mathrm{m}^{3} /$ year, which was taken from [26]; $x_{2}$ - the size of population [27].

We also develop a model of linear change over the years of the average tariff for MSW management services $\left(y_{2}, \mathrm{UAH} / \mathrm{m}^{3}\right)$ for the purpose of full estimation of the expected revenues for the provision of MSW management services for the second category of consumers - budgetary institutions of the Poltava sub-region.

We propose to consider the equation that describes this model as a linear regression, for which the following coefficients are found

$$
\hat{y}_{2}=-6605.79+3.30 \cdot x .
$$

We will assume that in the inertial scenario of the economy development of the Poltava sub-region: $x_{3}$ - the volume of creation of MSWs by budgetary institutions relative to 2018 will increase by $10 \%$ and on average $x_{3}=140741.23 \cdot 1.1=154815.35\left(\mathrm{~m}^{3}\right)-$ and longterm horizons will remain constant in order to calculate
$D_{t b}$ - the expected revenue from the provision of MSW management services for budgetary institutions, UAH million.

Hence

$$
D_{t b}=y_{2} \cdot 10^{-6} \cdot x_{3} \text {. }
$$

At the same time, we will develop a model of linear change over the years of the average tariff for MSW management services $\left(y_{3}, \mathrm{UAH} / \mathrm{m}^{3}\right)$ for the last category of consumers - other consumers of services in the field of MSW management in the Poltava sub-region.

It was proposed to consider the equation that describes this model as a linear regression, whose coefficients, similar to the previous models, are found by the least squares method

$$
\hat{y}_{3}=-6305.53+3.15 \cdot x .
$$

The correlation coefficients for the linearized model (1) $-r=0.88$, for model (3) $-r=0.89$ and for (5) $r=0.88$ are quite close to one, indicating that there is a close relationship in all the proposed models.

The Student's $t$-test showed that the calculated criterion $t=5.18$ for (1), $t=5.45$ for (3) and $t=5.26$ for (5) is larger than the tabular $t_{c r}=2.306$, found at the significance level $\alpha=0.05$, that is, with $95 \%$ reliability, we can assume that the regression coefficients are found correctly.

The Fisher's test verifies that the calculation criterion $F=26.78$ for (1), $F=29.74$ for (3) and $F=27.71$ (5) is larger than $F_{c r}=5.32$ found at $\alpha=0.05$, which gives reason to ascertain the adequacy of the proposed models with statistical data.

Designating $D_{t i}$ as revenue from the provision of MSW management services for other institutions and $D_{t}$ as the aggregate revenue from the provision of MSW management services, depending on tariff changes, we have

$$
D_{t}=D_{t n}+D_{t b}+D_{t i}
$$

Table 2. The composition of MSW by categories of houses, $\%$.

\begin{tabular}{|c|c|c|c|c|c|c|}
\hline $\begin{array}{c}\text { Waste } \\
\text { components }\end{array}$ & $\begin{array}{c}\text { Poltava multi- } \\
\text { storey } \\
\text { buildings }\end{array}$ & $\begin{array}{c}\text { Poltava } \\
\text { private } \\
\text { houses }\end{array}$ & $\begin{array}{c}\text { Cities with more } \\
\text { than 5000 multi- } \\
\text { storey buildings }\end{array}$ & $\begin{array}{c}\text { Cities with } \\
\text { more than 5000 } \\
\text { private houses }\end{array}$ & $\begin{array}{c}\text { Large population } \\
\text { settlements (1000-5000 } \\
\text { inhabitants) }\end{array}$ & $\begin{array}{c}\text { Small settlements } \\
\text { (smaller than 1000 } \\
\text { inhabitants) }\end{array}$ \\
\hline Organic waste & 43.3 & 37.1 & 29 & 19 & 14 & 19.3 \\
\hline Paper & 9 & 7 & 9 & 7 & 8 & 13 \\
\hline Plastic & 12 & 13 & 13 & 13 & 17 & 11 \\
\hline Glass & 11 & 18 & 15 & 21 & 2 & 24 \\
\hline Metal & 1.1 & 1.2 & 0.8 & 1.1 & 46 & 3.8 \\
\hline Others & 23.6 & 23.7 & 33.2 & 38.9 & 100 & 40.5 \\
\hline Total & 100 & 100 & 100 & 100 & 100 \\
\hline
\end{tabular}

Table 3. Tariffs for utilities in the field of MSW management within the Poltava sub-region, $\mathrm{UAH} / \mathrm{m}^{3}$ with ValueAddedTax (VAT).

\begin{tabular}{|l|c|c|c|c|c|c|c|c|c|c|}
\hline \multirow{2}{*}{ Average approved tariff of MSW providing services for } & \multicolumn{9}{|c|}{ Years, $\boldsymbol{x}$} \\
\cline { 2 - 8 } & $\mathbf{2 0 0 9}$ & $\mathbf{2 0 1 0}$ & $\mathbf{2 0 1 1}$ & $\mathbf{2 0 1 2}$ & $\mathbf{2 0 1 3}$ & $\mathbf{2 0 1 4}$ & $\mathbf{2 0 1 5}$ & $\mathbf{2 0 1 6}$ & $\mathbf{2 0 1 7}$ & $\mathbf{2 0 1 8}$ \\
\hline population with VAT, UAH $/ \mathrm{m}^{3}, y_{1}$ & 12.40 & 18.50 & 29.29 & 29.29 & 29.29 & 29.29 & 30.20 & 30.20 & 49.52 & 58.35 \\
\hline budgetary institutions with $\mathrm{VAT}, \mathrm{UAH} / \mathrm{m}^{3}, y_{2}$ & 18.60 & 24.70 & 35.93 & 35.93 & 35.93 & 35.93 & 36.10 & 36.50 & 52.96 & 56.73 \\
\hline other consumers with VAT, $\mathrm{UAH} / \mathrm{m}^{3}, y_{3}$ & 27.10 & 34.10 & 41.50 & 41.50 & 41.50 & 41.50 & 41.80 & 43.20 & 59.86 & 63.83 \\
\hline
\end{tabular}


It was developed multivariable nonlinear regression for forecasting $D_{t}$ as a model for the impact of tariff policy on the value of revenue from the provision of MSW management services, which looks like

$$
\begin{gathered}
D_{t}=-65.045+540.392 \cdot\left(\frac{y_{1}}{10^{2}}\right)^{2}+797.251 \cdot \frac{y_{2}}{10^{2}}+ \\
26.115 \cdot\left(\frac{y_{3}}{10^{2}}\right)^{-0.33}
\end{gathered}
$$

The regression coefficients were found after linearization using the least squares method in matrix form, with preliminary smoothing of the initial data as time series.

The determination coefficient is quite close to one: $R^{2}=0.685$, and in addition the calculation criterion $F=25.344$ is greater than the table criterion $F_{c r}=4.76$, found at the significance level $\alpha=0.05$, which confirms the adequacy of the proposed model with statistical data.

Let's create a model of nonlinear change of tariff threshold of availability of MSW providing services MSW $\left(y_{11}, \mathrm{UAH} / \mathrm{m}^{3}\right)$ for the population of Poltava subregion by years $(x)$. We propose to consider the equation that describes this model as a quadratic regression, the coefficients of which are found by the method of least squares, with preliminary linearization

$$
\hat{y}_{11}=-15024.54+0.00373 \cdot x^{2} .
$$

It is close to unit, indicating a close relationship for a linearized model $r=0.9$. The calculation criteria $t=5.76$ and $F=33.23$ are larger than the table values, i.e. with $95 \%$ reliability, we can assume that the regression coefficients are found correctly and the proposed model is adequate for the statistics.

\section{Results and discussion}

The values are summarized in Table 4 which were calculated by (1) - (8) for the period 2020-2040.

The regression graphs of (1) - a solid, and (8) - a dotted lines, together with the corresponding statistics points, are shown in Fig. 1.

The graphs make it possible to observe the projected increase in tariffs on MSW management for the population at the current rate of growth, provided that tariffs are increased to the level of the tariff threshold of service availability, which will also increase in proportion to the average income per household.

Currently, the tariff threshold for accessibility of services to the population is almost in 3.8 times higher than the tariff set by the local self-government bodies of Poltava sub-region at the end of 2018. Therefore the risk of late payment of consumed MSW management services in the medium and long term horizons is expected, it will increase by almost $1 / 3$, i.e. it will reach the level of $17.9 \%$.

\begin{tabular}{|c|c|c|c|c|c|}
\hline \multirow{2}{*}{ Index } & \multicolumn{5}{|c|}{ Years } \\
\hline & 2020 & 2025 & 2030 & 2035 & 2040 \\
\hline Population forecast, persons, $x_{2}$ & 453049 & 452235 & 440930 & 429907 & 419160 \\
\hline Expected formation of MSW, $\mathrm{m}^{3}$ person, $x_{1}$ & 1.92 & 2.05 & 2.13 & 2.21 & 2.38 \\
\hline Volume of MSW formation by population, $\mathrm{m}^{3}, x_{1} \cdot x_{2}$ & 869854.1 & 927081 & 939180 & 950094 & 997600 \\
\hline Tariff forecast for MSW providing services per person with VAT, UAH/m ${ }^{3}, y_{1}$ & 56.80 & 76.22 & 95.69 & 115.21 & 134.78 \\
\hline Revenue from the providing services to the population, UAH million, $D_{t n}$ & 49.4 & 70.7 & 89.9 & 109.5 & 134.4 \\
\hline Risk of delay with payment, UAH million & 5.8 & 8.3 & 10.5 & 12.8 & 15.8 \\
\hline Volume of MSW formation by budgetary institutions, $\mathrm{m}^{3}, x_{3}$ & 154815.3 & 154815.3 & 154815.3 & 154815.3 & 154815.3 \\
\hline Tariff forecast for budgetary institutions with VAT, UAH $/ \mathrm{m}^{3}, y_{2}$ & 58.3 & 74.8 & 91.3 & 107.8 & 124.3 \\
\hline Revenue from the providing services to budgetary institutions, UAH million, $D_{t b}$ & 9.0 & 11.6 & 14.1 & 16.7 & 19.2 \\
\hline Volume of MSW formation by other consumers, $\mathrm{m}^{3}$ & 81123.24 & 48872.18 & 103556.5 & 182389.9 & 237608.2 \\
\hline Tariff for other consumers with VAT, UAH $/ \mathrm{m}^{3}, y_{3}$ & 64.1 & 79.8 & 95.6 & 111.3 & 127.1 \\
\hline Revenue from providing services to other consumers, UAH million, $D_{t i}$ & 5.2 & 3.9 & 9.9 & 20.3 & 30.2 \\
\hline $\begin{array}{l}\text { Revenue from providing services according to the MSW, depending on tariffs, } \\
\text { UAH million, } D_{t}\end{array}$ & 63.6 & 86.2 & 113.9 & 146.5 & 183.8 \\
\hline Volumes of formation of plastic, $\mathrm{m}^{3}$ & 110993.4 & 118295.6 & 119839.5 & 121232.1 & 127293.9 \\
\hline Volumes of plastic formation, $\mathrm{t}$ & 18646.89 & 19873.67 & 20133.03 & 20366.99 & 21385.37 \\
\hline of which are subject to processing, $\mathrm{t}$ & 17155.1 & 18283.7 & 18522.3 & 18737.6 & 19674.5 \\
\hline Production volumes of finished goods, $\mathrm{t}$ & 17155.1 & 18283.7 & 18522.3 & 18737.6 & 19674.5 \\
\hline including pure PET flakes, $\mathrm{t}$ & 13037.88 & 13895.61 & 14076.95 & 14240.58 & 14952.62 \\
\hline secondary crystalline granules, $\mathrm{t}$ & 4117.22 & 4388.09 & 4445.35 & 4497.02 & 4721.88 \\
\hline Price of pure PET flakes, thousand UAH/t & 21.5 & 23.6 & 25.8 & 28.3 & 31.0 \\
\hline Price of secondary crystalline granules, thousand UAH/t & 27.0 & 29.5 & 32.3 & 35.5 & 38.9 \\
\hline Revenue from the sale of finished goods, million, UAH & 391.4 & 457.3 & 506.8 & 562.6 & 647.2 \\
\hline including pure PET flakes, million, UAH & 280.3 & 327.9 & 363.2 & 403.0 & 463.5 \\
\hline secondary crystalline granules, million, UAH & 111.1 & 129.4 & 143.6 & 159.6 & 183.7 \\
\hline Revenue from electricity supply, million, UAH & 122.5 & 130.6 & 132.3 & 133.8 & 140.5 \\
\hline Total revenue, million, UAH & 577.5 & 674.1 & 753 & 842.9 & 971.5 \\
\hline
\end{tabular}

Table 4. Forecasting data of the MSW recycling eco-project for the period 2020-2040 - the inertial economic development scenario of Poltava sub-region. 


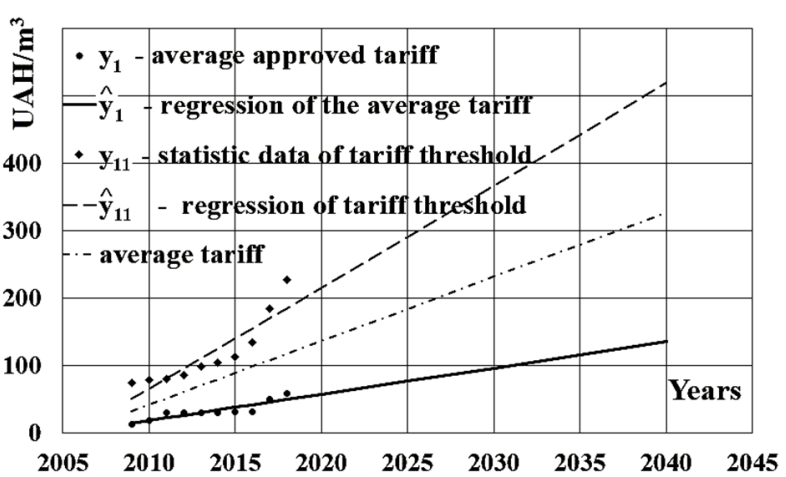

Fig. 1. Comparison of the existing tariffs of MSW providing services for population and their threshold.

Let's calculate the average arithmetic between the forecast tariff for the previous scenario and the tariff threshold for the availability of services (Fig. 1 the graph of which is shown by a dashed dotted line). The average tariff would be used for estimation of the profitability of the eco-project for recycling plastic waste for the period 2020-2040 under the innovative scenario of economic development of the Poltava sub-region tariff for the provision of MSW management services,

Let's consider the impact of different tariffs (one by one) on the income $D_{t}$ (Fig. 2) under the condition of constant of other tariffs using the multifactor nonlinear model (7). We put constant the tariff for budgetary institutions at the level of $y_{2}=60 \mathrm{UAH} / \mathrm{m}^{3}$ and the tariff for other consumers of solid waste management services at the level of $y_{3}=65 \mathrm{UAH} / \mathrm{m}^{3}$.

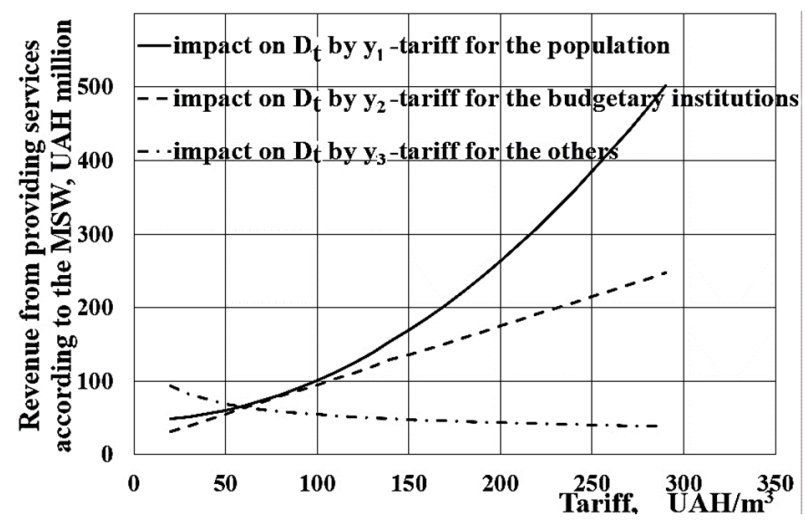

Fig. 2. Tariffs' impact on the revenue from providing services according to the MSW.

Let's study the impact of changing of the tariff on MSW management for population $y_{1}$ on the profitability of waste recycling eco-project, which is shown as a solid line in Fig. 2. The tariff for budgetary institutions and the tariff for other consumers were considered as constants at the level of $y_{2}=60 \mathrm{UAH} / \mathrm{m}^{3}$ and at the level of $y_{3}=65 \mathrm{UAH} / \mathrm{m}^{3}$. The dotted line in Fig. 2 characterizes the impact of the tariff change for budgetary institutions $y_{2}$ on the profitability of the waste recycling eco-project, when the next tariffs were considered as constants at the levels of $y_{1}=55 \mathrm{UAH} / \mathrm{m}^{3}$ and $y_{3}=65 \mathrm{UAH} / \mathrm{m}^{3}$. The dashed dotted line in Fig. 2 allows us to observe the impact of the tariff change for other consumers of $y_{3}$ on the profitability of the waste recycling eco-project, $y_{1}=55 \mathrm{UAH} / \mathrm{m}^{3}$ and $y_{2}=60 \mathrm{UAH} / \mathrm{m}^{3}$. The negative free coefficient in (7) shows that, the waste recycling enterprise will losses suffer if the tariffs are reduced to zero.

We construct the appropriate surface (Fig. 3) to study the impact on the expected income of a MSW recycling eco-project at the same time as two factors - the impact of changing of the tariffs on MSW management services for the population $y_{1}$ and for budgetary institutions $y_{2}$, taking into account the constant tariff $y_{3}=65 \mathrm{UAH} / \mathrm{m}^{3}$ according to the model (7).

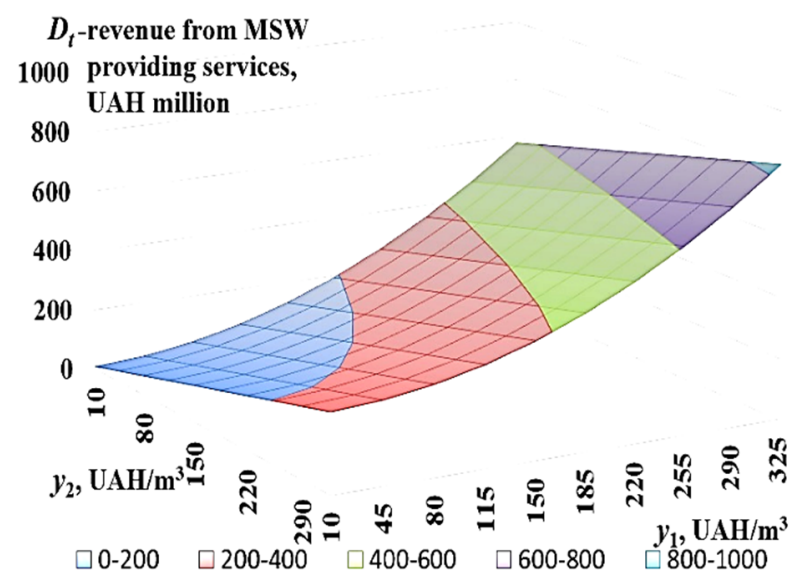

Fig. 3. The surface of the tariffs' impact on the revenue from providing services according to the MSW.

The calculated predictive values for the expected income from recycling MSW Eco-Project by (1) - (8) for innovative scenario of economic development for Poltava sub-region for the period 2020-2040 years are summarized in Table 5.

The average tariff for MSW providing services for the population, calculated as the average arithmetic mean the value of projected tariffs for the population in the previous scenario and the tariff threshold for the availability of services in the medium and long-term horizons will increase approximately 2.4 times, which at the same time requires an increase in tariffs and for the consumer in other categories.

According to the innovation scenario of the Poltava sub-region's economic development, the recycle of the eco-project on waste recycling is accelerated by almost $20 \%$ due to exceeding the level of profitability in comparison with the expected revenue under the inertial scenario of the development of the sub-regional economy.

However, in both inertial and innovative scenarios for the development of the economy of the Poltava subregion, the eco-project for municipal waste recycling is accompanied by both an environmental and economic effect, which makes it an investment attractive, providing a "green" economic growth of the sub-region.

The results obtained are novel and unfortunately cannot be compared with known information due to the different conditions of project implementation. Thus, a similar project is being implemented by the European Union for the Territorial Cooperation with Limited Liability of TISA in the Transcarpathian region, but due to its specific territorial location and special geographical 
features, it is not appropriate to use such areas of landfills as in the Poltava region. As for foreign projects, they are enough large-scale. The present work shows that small recycling processing plants with full self-financing are more acceptable to Ukrainian territorial communities.

Table 5. Forecasting data of the MSW recycling eco-project for the period 2020-2040 - the innovative economic development scenario of Poltava sub-region.

\begin{tabular}{|c|c|c|c|c|c|}
\hline \multirow{2}{*}{ Index } & \multicolumn{5}{|c|}{ Years } \\
\hline & 2020 & 2025 & 2030 & 2035 & 2040 \\
\hline Population forecast, persons, $x_{2}$ & 453049 & 452235 & 465802 & 507722 & 543263 \\
\hline Expected formation of MSW, $\mathrm{m}^{3}$ person, $x_{1}$ & 1.92 & 2.05 & 2.13 & 2.21 & 2.38 \\
\hline Volume of MSW formation by population, $\mathrm{m}^{3}, x_{1} \cdot x_{2}$ & 869854.1 & 985872.3 & 1113267 & 1274382 & 1510271 \\
\hline Tariff forecast for MSW providing services per person with VAT, UAH $/ \mathrm{m}^{3}, y_{1}$ & 135.95 & 183.43 & 231.03 & 278.75 & 326.58 \\
\hline Revenue from the providing services to the population, UAH million, $D_{t n}$ & 118.26 & 180.84 & 257.20 & 355.23 & 493.22 \\
\hline Risk of delay with payment, UAH million & 13.9 & 21.2 & 30.2 & 41.7 & 57.9 \\
\hline Volume of MSW formation by budgetary institutions, $\mathrm{m}^{3}, x_{3}$ & 154815.3 & 154815.3 & 154815.3 & 154815.3 & 154815.3 \\
\hline Tariff forecast for budgetary institutions with VAT, $\mathrm{UAH} / \mathrm{m}^{3}, y_{2}$ & 139.72 & 180.18 & 220.59 & 260.97 & 301.33 \\
\hline Revenue from the providing services to budgetary institutions, UAH million, $D_{t b}$ & 21.63 & 27.89 & 34.15 & 40.40 & 46.65 \\
\hline Volume of MSW formation by other consumers, $\mathrm{m}^{3}$ & 453013.2 & 619928.0 & 789083.8 & 933480.9 & 1010504 \\
\hline Tariff for other consumers with VAT, $\mathrm{UAH} / \mathrm{m}^{3}, y_{3}$ & 153.39 & 192.17 & 230.85 & 269.49 & 308.10 \\
\hline Revenue from providing services to other consumers, UAH million, $D_{t i}$ & 54.82 & 96.71 & 150.27 & 207.52 & 250.18 \\
\hline $\begin{array}{l}\text { Revenue from providing services according to the MSW, depending on tariffs, } \\
\text { UAH million, } D_{t}\end{array}$ & 194.71 & 305.44 & 441.62 & 603.15 & 790.05 \\
\hline Volumes of formation of plastic, $\mathrm{m}^{3}$ & 110993.4 & 125797.3 & 134467.8 & 137688.9 & 148687.8 \\
\hline Volumes of plastic formation, $\mathrm{t}$ & 18646.89 & 21133.95 & 22590.59 & 23131.74 & 24979.55 \\
\hline of which are subject to processing, $\mathrm{t}$ & 17155.14 & 19443.23 & 20783.34 & 21281.2 & 22981.19 \\
\hline Production volumes of finished goods, $\mathrm{t}$ & 17155.14 & 19443.23 & 20783.34 & 21281.2 & 22981.19 \\
\hline including pure PET flakes, $\mathrm{t}$ & 13037.91 & 14776.85 & 15795.34 & 16173.71 & 17465.7 \\
\hline secondary crystalline granules, $\mathrm{t}$ & 4117.23 & 4666.38 & 4988 & 5107.49 & 5515.49 \\
\hline Price of pure PET flakes, thousand UAH/t & 22.0 & 24.1 & 26.4 & 29.0 & 31.7 \\
\hline Price of secondary crystalline granules, thousand UAH/t & 27.5 & 30.1 & 33.0 & 36.2 & 39.7 \\
\hline Revenue from the sale of finished goods, million, UAH & 400.06 & 496.58 & 581.6 & 653.93 & 772.63 \\
\hline including pure PET flakes, million, UAH & 286.83 & 356.12 & 417.00 & 469.04 & 553.66 \\
\hline secondary crystalline granules, million, UAH & 113.22 & 140.46 & 164.60 & 184.89 & 218.97 \\
\hline Revenue from electricity supply, million, UAH & 145.89 & 165.35 & 176.75 & 180.98 & 195.44 \\
\hline Total revenue, million, UAH & 740.67 & 967.37 & 1199.97 & 1438.06 & 1758.12 \\
\hline
\end{tabular}

\section{Conclusion}

Sustainable development is a new worldview model of Ukraine's development, under which the transformation from a linear to a circular model of the economy has begun to balance the three interconnected components economic growth, environmental protection and social protection of all members of the society. These items achievement key is adhering to the principles of sustainable development by regions, cities and territories, which today face one of the largest and most significant problems, which not only impedes their socio-economic development but also leads to the destruction of the environment - this is the problem of solid waste generation. The decision on this problem is to create an enabling environment for the successful implementation of eco-projects for MSW recycling of, and an effective tariff policy for MSW management services, which will not have a compensatory but stimulating character unlike the existing ones.

The correctness of the above statement is shown by the development of the nonlinear multi-factors economicmathematical model of the relationship between tariffs and profitability of eco-project for the construction of MSW recycling plant in the Poltava sub-region using correlation-regression analysis. The validity of the proposed model is proved. Thus, the model makes possible to clearly determine the dependence of the expected eco-project revenue from the change in tariffs for MSW management services for each of the consumer categories. However, we recommend introducing a single tariff without subdivision of consumers into categories, which will ensure transparency of the tariff policy. According to the results of the study, it was allowed establishing deficiencies and rigidities in tariffs and services of MSW. The model helps to identify proposals for its effectiveness strengthen in ensuring compliance with the principles of sustainable development of the economy not only of regions but also of the whole country, and to outline vectors creation of eco-cities in Ukraine.

\section{References}

1. V. Okors'kyi, P. Orlovs'kyi, Economics and Society 20, 504-512 (2019)

2. The Verkhovna Rada of Ukraine, The Law about waste https://zakon3.rada.gov.ua/laws/show/187/98\%D0\%B2\%D1\%80. Accessed 1 Aug 2019

3. The European Parliament and the Council. Ramkova Dyrektyva Pro vidkhody (2008), 
https://menr.gov.ua/news/31288.html. Accessed 19 Jul 2019

4. Handling of household and similar wastes of Ukraine - 2018. Statistical yearbook. State Statistics Service of Ukraine, Kyiv (2019), https://www.ukrstat.gov.ua. Accessed 14 Aug. 2019

5. MSW in Ukraine: development potential (2019), https:/www.ifc.org/wps/wcm/connect. Accessed 29 Aug 2019

6. M.F. Nasirov, Investments: practice and experience 16, 61-66 (2018)

7. Sub-regional management strategy for household solid waste in Poltava's sub-region (GFA Consulting Group, Poltava, 2016)

8. I.L. Yakymenko, O.M. Salavor, Y.B. Shapovalov, Eco. Sciences 4(23), 87-91 (2018)

9. L.A. Svistun, A.A. Rozhko, Young Scientist 12(39), 861-869 (2016)

10. V.V. Duryts'ky, H.V. Durnyts'ka, Scientific Bulletin of UNFU 25(3), 193-199 (2015)

11. S.K. Rao, MSW Management in Visakhapatnam City, India, IJEAT 8(6), 3604-3607 (2019). doi:10.35940/ijeat.F9357.088619

12. N. Mazlan, A.S. Saudi, N.Z. Shafii, M.H. Amran, N.L. Zakri, The Impact of Economic Class on Solid Waste Generation Pattern in Capital City of Kuala Lumpur, Malaysia, IJEAT 8(6), 4807-4812 (2019). doi:10.35940/ijeat.F9097.088619

13. X. Bing, J.M. Bloemhof, T.R. Ramos, A.P. BarbosaPovoa, C.Y. Wong, J.G. van der Vorst, Research challenges in municipal solid waste logistics management. Waste management 48, 584-592 (2016). doi:10.1016/j.wasman.2015.11.025

14. M.M. Mian, X. Zeng, A.A. Nasry, S.M. AlHamadani, Municipal solid waste management in China: a comparative analysis. J. of Mater. Cycles \& Waste Management 19(3), 1127-1135 (2017). doi:10.1007/s10163-016-0509-9

15. H. Jafari, S. R. Hejazi, M. Rasti-Barzoki, Sustainable development by waste recycling under a threeechelon supply chain: A game-theoretic approach. J. of Cleaner Production 142, 2252-2261 (2017). doi:10.1016/j.jclepro.2016.11.051

16. C. Pan, D. Bolingbroke, K.T. Ng, A. Richter, H.L. $\mathrm{Vu}$, The use of waste diversion indices on the analysis of Canadian waste management models, J. of Mater. Cycles \& Waste Management 21(3), 478-487 (2019) doi:10.1007/s10163-018-0809-3

17. X. Meng, Z. Wen, Y. Qian, Multi-agent based simulation for household solid waste recycling behaviour. Resources, Conservation and Recycling 128, 535-545 (2018). doi:10.1016/j.resconrec.2016.09.033

18. C. Ackermann, Recyklung von Kunstsofen (Erich Schmidt, Berlin, 1996)

19. J. Rifkin, Die dritte industrielle Revolution. Die Zukunft der Wirtschaft nach dem Atomzeitalter
(Campus Verlag, Frankfurt am Main/New York, 2011)

20. A. Tkachenko, N. Levchenko, T. Pozhuieva, N. Chupryna, Innovative Approach to Evaluation of the Decoupling Phenomena in Making Decision on Investment of Agro-Business. IJRTE 8(3C), 38-44 (2019). doi:10.35940/ijrte.C1007.1183C19

21. T. Dovha, Biznesinform 1, 125-131 (2013)

22. S.N. Bobylev, A.A. Goryacheva, V.I. Nemova, Electr. Newsletter 64, 34--4 (2017)

23. M. Pal, P. Bharati, Applications of Regression Techniques (Springer, Singapore, 2019)

24. G. Shyshkanova, in Proceedings of the $1 s t$ International Conference on System Analysis \& Intelligent Computing, Kiev, Ukraine, 8-12 Oct. 2018. doi:10.1109/SAIC.2018.8516805

25. The Ministry of Housing and Communal Services of Ukraine, Pro zatverdzhennia Pravyl vyznachennia norm nadannia posluh $\mathrm{z}$ vyvezennia pobutovykh vidkhodiv (2010),

https://zakon.rada.gov.ua/laws/show. Accessed 07 Sep 2019

26. Demographic Forecast of Poltava's population till 2050 (2018), https://drive.google.com/file/d/0B9bbOkCYFnOhb3 RCcmUxWmgwb00/view. Accessed 12 Sep 2019

27. Planning and construction of territories (Minregion, Kyiv, 2018), http://dipromisto.gov.ua/files/NMD/DBN_B.2.212_2018.pdf. Accessed 3 Sep 2019

28. Complex program of MSW management in Poltava's region 2017-2021 (2017)

29. The Verkhovna Rada of Ukraine, The Law About housing \& communal services (2013)

30. Cabinet of Ministers of Ukraine. The tariff formation order for transportation services MSW (2014)

31. Cabinet of Ministers of Ukr. About changes (2019), https://search.ligazakon.ua>link1>KP190318. Accessed 7 Jul 2019

32. The Verkhovna Rada, The draft Law about waste management (2015),

http://w1.c1.rada.gov.ua/pls/zweb2/webproc4_1?pf3 511=67094. Accessed 22 Sep 2019

33. ISO 1043-1:2011 Plastics. Part 1 (2011) 